\title{
Cost Analysis of Using Recycled Water in Container Production: A Case Study of Southern New Jersey
}

\author{
Alyssa J. DeVincentis ${ }^{1}$, Robin G. Brumfield, and Paul Gottlieb \\ Department of Agriculture, Food, and Resource Economics, Rutgers, The \\ State University of New Jersey, 55 Dudley Road, New Brunswick, NJ 08901- \\ 8520
}

James R. Johnson

Cooperative Extension of Cumberland County, Rutgers New Jersey Agricultural Experiment Station, 291 Morton Avenue, Millville, NJ 08332

Additional index words. UV light, chlorine, ozone, microbial filtration, water disinfection

\begin{abstract}
Management of agricultural irrigation water is extremely important as fresh water resources are being depleted on a global scale. In anticipation of regulatory restrictions, several greenhouse and nursery operations in New Jersey have implemented systems that disinfect and recycle their irrigation water. This study compared the disinfection methods at two greenhouses and three container nurseries, focusing on the qualitative and quantitative benefits of using chlorine gas, ultraviolet light, ozone, and copper for water disinfection. The data were collected during on-site visits where the growers were interviewed on camera. A cost analysis was performed, but the most efficient disinfection technique could not be determined due to the variability between businesses and various unquantifiable benefits of proactive water management recycling, such as improved plant health, decreased fungicide and fertilizer use, a cleaner operation, reduced runoff, reduced pressure on aquifers, and increased customer satisfaction. The investment and maintenance costs per hectare and $1000 \mathrm{~L}$ were calculated, which can be useful reference tools for growers. The net present value (NPV) of each disinfection system was calculated to analyze the profitability of the investments. All three container nurseries had positive NPV values and profitable investments, which improved with cost sharing from the National Resource Conservation Service. This information will be useful in the future as growers throughout the state, and country, may be required to deal with the stricter regulation of their irrigation runoff.
\end{abstract}

Fresh water is a valuable, finite commodity that is becoming more costly and difficult to access every day. Water supply and demand studies have revealed several emerging problems including unsustainable wateruse patterns and water-scarce regions with large at-risk populations (Amarasinghe and Smakhtin, 2014). The availability of water is dwindling rapidly, and the emerging water shortage could be the defining crisis of the 21 st century as the global population continues to expand, but our water withdrawals are increasing twice as fast as population (Majsztrik et al., 2011). As a local resource, water is adequate in some locations but

\footnotetext{
Received for publication 14 Oct. 2014. Accepted for publication 6 June 2015.

The authors received Rutgers Institutional Review Board protocol no. E14-203 exemption 2. This project was supported by the New Jersey Agricultural Experiment Station and by the USDA-National Institute for Food and Agriculture, Multistate Hatch Project NJ02278, accession number 206039 and the Rutgers Aresty Foundation.

The contents are solely the responsibility of the authors and do not necessarily represent the official views of the USDA or NIFA.

${ }^{1}$ Corresponding author. E-mail: brumfield@aesop. rutgers.edu.
}

nonexistent in others. Increased demand by both urban and agricultural users has led to a world where large river systems no longer drain into the ocean and water rationing is required in some major cities across the globe.

This decline in fresh water availability will affect many industries. Agriculture uses more water than any other human activity; however, only $40 \%$ of irrigated water reaches crops because of inefficient irrigation techniques worldwide (Pimentel et al., 1997). This study focuses on the horticultural industry. Ornamental production uses large volumes of water per hectare for both containers and greenhouses. These operations normally pull water from local aquifers, but access may be affected by water shortages.

In general, water costs are higher in the west, particularly in California, which leads to higher production cost and reduced profit. In an effort to conserve this valuable resource, there is a strong push for agricultural and horticultural industries to recycle irrigation water (Economics Consulting Service, 2008; World Bank, 2006). Growers want to manage water without changing their production schedules and the value of their crops (Majsztrik et al., 2011). One way to manage water runoff in container production is to convey rain and irrigation runoff to a containment pond for reuse (Yeager, 2008).

Recycling irrigation runoff allows for the reuse of nutrients from containers, minimizes discharge from the nursery site, and the water can even be superior to groundwater if it is mixed with rainwater (Yeager, 2008). Growers have implemented water recycling systems because they anticipate restricted water access in the near future. Containment ponds supply a "buffer" that allows growers to reduce their reliance on wells or municipal water sources in emergencies (Powell, 2014). However, recycled water poses challenges to the industry. Runoff is collected in catch basins for reuse, where a unique ecosystem forms. The water quality of these catch basins can fluctuate greatly throughout the seasons, and can support a variety of fungal and bacterial pathogens (Hong et al., 2008). The greatest threat in the use of water runoff consists of microbial pathogens that cause waterborne diseases, putting the health of an entire nursery or greenhouse at risk if recycled water is not properly managed and disinfected (Meador et al., 2012).

Plant pathogens in recycled water could potentially harm plants and spread disease, reducing sellable yields and hurting the grower financially. Furthermore, the grower may have to increase chemical use to control disease outbreaks, further adding to production costs and potential water pollution (Stewart-Wade, 2011). Fungi and fungallike organisms in water runoff can cause disease in various crops if that water is recycled without disinfection. Some examples of such organisms include various species of Phytophthora and Pythium, which cause root crown rots and foliage blight, respectively. Many other bacteria, fungi, nematodes, and viruses can threaten nursery and greenhouse crops and have been found in irrigation runoff (Yeager, 2008).

Proper water disinfection is a critical step to ensuring that recycled irrigation water does not spread plant pathogens and increase disease risk (Stewart-Wade, 2011). Integrated water resource management is advocated by The Global Water Partnership, which defines it as "a process that promotes the coordinated development and management of water, land, and related resources to maximize the resultant economic and social welfare in an equitable manner without compromising the sustainability of vital ecosystems" (Global Water Partnership, 2000).

A grower must decide what level of disinfection is required based on the pathogens to which the crops being grown are susceptible and must also decide on an acceptable tolerance threshold for plant loss due to disease. The grower must be dedicated to hygienic operations and frequent monitoring to ensure that proper disinfection takes place, and be willing to invest in the necessary equipment. Disinfection techniques including ultraviolet light, chlorine gas, ozone, and copper require strategic implementation to work effectively. For example, although copper is an essential element for plant growth, an excessive amount 
is toxic and requires careful monitoring (Zheng et al., 2004).

The costs and benefits of various irrigation systems can shed light on the affordability of water recycling. Reclaimed water is an economical water resource if proper risk management practices are used (Chen et al., 2013). According to Alcon et al. (2012), using a mixture of reclaimed and surface water is the best option when accounting for "intangible" social and environmental benefits. A variety of technologies are available to address the major risk areas in irrigation water quality, which include salinity, pathogens, nutrients, and heavy metals (NortonBrandao et al., 2013). Each technique has unique abilities, advantages, and disadvantages including a range of operating and investment costs. For example, ultraviolet light is recommended by several guidelines as the best disinfection technology without excessive costs, while reverse osmosis technology has both high capital and operation costs (Norton-Brandao et al., 2013).

Although the process may be complicated, recycled and properly treated water has no shortage of benefits from both economic and environmental standpoints. The process reduces the discharge of untreated water into nearby water bodies and encourages producers to treat their recycled water efficiently to protect their crops. It relieves pressure on surface waters and slows down the depletion of groundwater, which supports healthy ecosystems and decreases the need for new water supply infrastructure such as dams and wells, which can damage local habitats or be costly to drill and maintain, respectively. Recycling water also recycles fertilizer within the system and may reduce fertilizer costs. Unfortunately, many of the spillover benefits described here are difficult to measure and are therefore excluded from a typical cost-benefit analysis (Schulte, 2011).

Water management has been a concern of growers in Europe for years, and reusing irrigation runoff is a popular technique. It provides a readily available water resource when restrictions limit access to ground or surface water (Yeager, 2008). Recycled water has been safely and successfully used in Florida for over 40 years. It was initially promoted to improve surface water quality by preventing runoff pollutants from entering surface water, but it now helps meet water shortages from increasing urban demand and has delayed saltwater intrusion on wells (Parsons et al., 2010). Recycled water has become a necessity to water-scarce California, which has imposed water management laws over the last decade, and in 2009 enacted The Water Conservation Act with the goal of increasing water use efficiency through urban and agricultural water conservation. It required that agricultural water suppliers (including farmers and anybody else who digs a well) adopt water management plans by the end of 2012 and update them every 5 years starting in 2015. These regulations have several required components, including that water suppliers implement efficient management practices that reduce water waste. If water suppliers fail to meet these requirements, they are not eligible for state water grants or loans (Anonymous, 2009). This California Act has set the standard for statewide water regulation laws, which many New Jersey growers anticipate will be forthcoming in their own state. This study looked at several growers in New Jersey who have made the decision to recycle their irrigation water in response to laws imposed in other states.

Still, other operations are hesitant to recycle their irrigation water when it is not required by the government. Many fear the spread of plant pathogens, which can be brought into a greenhouse by wind, insects, soil, transplants, seeds, and humans. In a recycled system, water that runs off from an infected plant can carry the disease to other plants if it is not disinfected properly. An entire operation can be threatened by one disease outbreak if it leads to significant crop loss (Powell, 2014). One grower cited the Ralstonia outbreak in the early 2000 s as a reason for their trepidation toward water recycling. Ralstonia solanacearum is a soilborne bacterial pathogen that enters the plant through the root system and causes the plant to wilt and eventually die. There are two races of the bacterium, and the occurrence of Race 3 requires federal quarantine because of the relative ease of transmission. It was found to infect common crops such as geranium (UMass Amherst Extension, 2013).

Growers throughout the United States have a decision to make whether to recycle their water now or wait for legislation that requires them to do so. The Natural Resource Conservation Service (NRCS) provides assistance to private landowners making this decision, offering financial and technical assistance to help manage natural resources in a sustainable manner without having to hire an engineer or consultant. They offer financial assistance through many programs including Agriculture Management Assistance, Conservation Stewardship Program, and the Environmental Quality Incentives Program (USDA Natural Resource Conservation Service New Jersey, 2014). These are valuable resources for growers.

The objective of this case study was to perform a cost analysis of various water disinfection techniques being used at horticultural operations in southern New Jersey. The goal was to determine the most costefficient disinfection method for recycled irrigation water from the Cohansey aquifer, and make policy suggestions based on the results. Only financial data reported by growers were included, so this is not a full environmental cost-benefit analysis of the practice. It is reasonable to assume that if investments such as these are profitable in strictly private terms, then net social benefits are even greater, because what will be missing from the analysis will mostly consist of hard-to-quantify environmental benefits.

\section{Materials and Methods}

For our study, five New Jersey growers were selected who used four types of disinfection: ozone, chlorine gas, ultraviolet light, and copper. The three container nurseries used a general watering technique where they collected runoff in a tailwater recovery basin, disinfected it, and mixed it with well water before redistribution. We assigned each operation a name based on their disinfection technique and will refer to them throughout the manuscript as Ultraviolet-lighters, Chlorinators, and ChlorinatorsXXX. Two of the nurseries used chlorine disinfection, so the $\mathrm{XXX}$ denotes the larger size of one of the operations. One greenhouse had flood floors and used a three-step disinfection, which we call the Flooders. The last greenhouse served as our control because they did not recycle their water. We refer to them as Drippers because they used drip irrigation.

During on-site interviews at five operations, growers shared their experiences and offered relevant financial information. Their experiences revealed costs and benefits, while their financial data were used to make comparisons of investment and maintenance costs per hectare, as well as maintenance costs per $1000 \mathrm{~L}$ of water applied.

A partial budget approach was used to conduct an economic analysis. In a traditional partial budget approach, changes in net income and net costs are used to calculate the profit attributable to a change in the operation. Changes in income from the decision to recycle water, however, were ignored in this study. There is no easy way to measure the income benefits of green marketability, although marketing appeal and consumer acceptance of various forms of ecofriendly pots have emerged (Hall et al., 2010). This leaves the analysis of change in net costs for each investment.

The reduced costs attributable to recycling included the foregone cost of drilling additional wells to provide enough water to maintain the current pump capacity. The cost of drilling a well was estimated to be $\$ 45,000$ with an approximate pump capacity of 1514 L per minute (LPM). This cost was allocated to the 10th year after initial investment because the need for the wells was probably not imminent when the recycling investments were made. This estimate was based on the Chlorinators' construction project during the spring of 2014. The investment for a 16-inch well included $\$ 10,000$ for drilling and casing, $\$ 20,000$ for the turbine (gear box, shaft, and prop in well), and $\$ 15,000$ for a power unit to run the turbine. The costs of maintaining wells, including pump replacement and power, were negligible for most of the businesses. The number of wells needed to maintain the current pump capacity was rounded to the nearest whole number. Although an average of $55 \%$ of the nursery water is horizontally pumped from catch basins, any change in the amount of power required for pumping was not included in this study because the pump capacities of wells in this area vary between 379 and 3785 LPM depending on the type of rock under the land. Pump capacities even vary among wells on the same property; therefore, we did not 
attempt to quantify potential savings from horizontal versus vertical pumping. Other reduced production costs were included in the reduced costs, such as decreased fungicide or fertilizer used.

Additional costs included capital and maintenance costs, which were recorded per hectare to allow for easy comparison. These calculations included total investment costs, even expansion projects by ChlorinatorsXXX and the Flooders done years after initial construction.

The NPV of the water treatment and recycling technology at each operation was calculated based on information collected in the partial budget. The NPV was calculated by discounting all financial flows to the present value and subtracting the present value of all outlays from the present value of all financial inflows, which are cost savings in this case (Keat and Young, 1996). The following equation was used to make these calculations:

$$
\mathrm{NPV}=\sum_{t=1}^{n} \frac{R_{t}}{(1+k)^{t}}-\sum_{t=0}^{n} \frac{O_{t}}{(1+k)^{t}}
$$

In this equation $n=$ last period (typically in years) of the project, $\mathrm{R}_{t}=$ cash inflow in period $t, \mathrm{O}_{t}=$ cash outflow in period $t$, and $k=$ discount rate (interest rate on a loan). The period of the project was estimated to be 30 years because that is the expected lifetime of most of the systems and their components after which time they would need a complete overhaul. The discount rate used based on the current Wall Street Journal 30-year fixed prime rate of $3.25 \%$ for May 2015 (Bankrate, 2015). Two separate NPVs were calculated for both the Ultraviolet-lighters and the Chlorinators, with and without cost sharing by the NRCS, which shows the benefit of public investment to those growers. All NPVs were estimated to the nearest whole dollar.

The following is an example of the values used to calculate the Ultraviolet-lighters' NPVs. The recycling system required a \$500,000 initial investment, annual cash inflows were estimated to be $\$ 100,000$ in the form of reduced fertilizer expenses, and annual cash outflows were estimated to be $\$ 19,000$ for maintenance. The additional inflow of $\$ 135,000$ during year 10 accounts for the opportunity cost of not having to drill three wells. The same information was used to calculate the second NPV, but the initial investment was reduced to $\$ 275,000$ to account for financial assistance from the NRCS. The discount rate of $3.25 \%$ was used in both calculations. This general approach was used to calculate the NPV of each operation.

\section{Results and Discussion}

The results of economic analyses are summarized in Table 1. The price of water disinfection varied greatly based on a business' disinfection preferences. Not surprisingly, there is a positive correlation between systems' costs and the complexity of the disinfection strategy.
The disinfection technique with the lowest capital cost per hectare was copper ionization used by the control, the Drippers. This operation did not want to risk the health of their entire operation by recycling, and instead used a strict water management technique to produce minimal runoff. The Drippers watered their plants on a wet/dry cycle using drip irrigation to deliver only enough water to the plant so it can get to the next day. They used a $0-5$ scale developed by Dr. Will Healy from Ball Horticultural to determine the level of moisture (Fisher et al., 2015). Their copper disinfection system was used to reduce algal growth on the floor of their propagation houses and improve cleanliness. This may be a good alternative for operations with similar concerns. They use less water than the other operations, which explains why they have the highest maintenance costs per $1000 \mathrm{~L}$. Their water management technique did not improve plant health according to their observations, but it did produce a cleaner operation and allowed them to easily communicate with their employees and customers about watering.

The Flooders had the highest capital cost per hectare because they used a threepronged disinfection technique. This operation used ozone, ultraviolet light, and beneficial microbes to disinfect, and reuse $100 \%$ of the water in their flood floor system, which they ensured with frequent monitoring. High cost did not deter this grower, who was motivated by environmental stewardship and has been concerned with their water use since the 1980s. This expensive system first removes chemicals with ozone, then destroys ozone and creates a free radical spike by running it through ultraviolet light, and the last step is biological filtration. Although previous research showed that flood floors were most profitable for producing potted plants, it may not hold true for operations that recycle their irrigation water and accrue this added expense (Uva and Weiler, 2001).

The cost of maintaining disinfection systems per $1000 \mathrm{~L}$ of water is useful for comparisons with local municipal water prices. (Although it is rare in New Jersey, some California growers must rely on municipal water to meet their irrigation demands.) Prices of municipal water vary from $\$ 0.003$ to $\$ 0.006 / \mathrm{L}$ in Philadelphia to San Francisco, respectively (Circle of Blue, 2015). None of the New Jersey operations had maintenance costs over $\$ 0.10 / 1000 \mathrm{~L}$. The Chlorinators' price of $\$ 0.02 / 1000 \mathrm{~L}$ may be an underestimate because that grower could not determine the operation's annual water usage on the recycled water zones of the property. Similarly, the Flooders' annual maintenance per $1000 \mathrm{~L}$ could not be determined due to a lack of data. Currently, municipal water prices are less than the cost of maintaining the nursery recycling systems, but data show that prices rose $41 \%$ since 2010 . If this trend continues, municipal water may not be the more affordable option in the future.

The four operations that use water disinfection to ensure the cleanliness of their recycled irrigation water are all from the same county in New Jersey, use well water from the Cohansey aquifer, and can be loosely compared with one another. These data showed that as the quantity of investment and maintenance costs per hectare increased, benefits were more significant. Some of these benefits could be easily quantified, including reduced production costs such as fertilizer and the foregone cost of drilling wells to maintain their pump capacity. Unfortunately, many costs and benefits of recycling irrigation water could not be easily quantified or included in the economic analysis.

One of these unquantified costs was the variability of replacing filters at the Ultravioletlighters' operation. Their ultraviolet treatment required a very thin and clear film of water to flow under ultraviolet light to destroy pathogens. Water from their ponds was filtered before treatment to ensure it will work. The lifetime of these filters was unpredictable because there is a lot of animal activity around their tailwater recovery pond, and these animals clog up the pipes and get caught in the filters. The Chlorinators and ChlorinatorsXXX did not need to filter before treatment, but they did have to worry about the danger of explosive chlorine gas and plant sensitivity to chlorine concentrations, which can vary greatly between species and influence plant quality, growth, and physiological performance (Cayanan et al., 2008).

Some benefits of this proactive water management that could not be quantified include improved plant health, reduced pressure on aquifers, increased customer satisfaction, and use as a marketing tool. All growers reported experiencing a "feel good" effect from their perception of "protecting the environment." The Ultraviolet-lighters reduced pressure on the aquifer and incorporated their watering strategy into the nursery's marketing. The treatment used by the Chlorinators has reduced algal growth in their pipes and will increase the lifetime of the nursery's infrastructure. The Chlorinators also incorporated water management into their environmentally conscious marketing, along with their composting and solar energy efforts.

Most importantly, growers tried to avoid the possibility of not being in compliance with future water conservation regulations. By staying ahead of the laws, these growers already adhered to the kinds of regulations imposed elsewhere, will avoid additional investments in the future, and were able to design their systems on their own terms with flexible timetables. This freedom was vital because it allowed growers to shop around for an appropriate system to fit their operations. Growers in California faced many challenges when they had to respond to strict water laws after they were put into effect. The New Jersey growers involved in this study have protected the future of their businesses by controlling their water use before it is mandated by the state. 


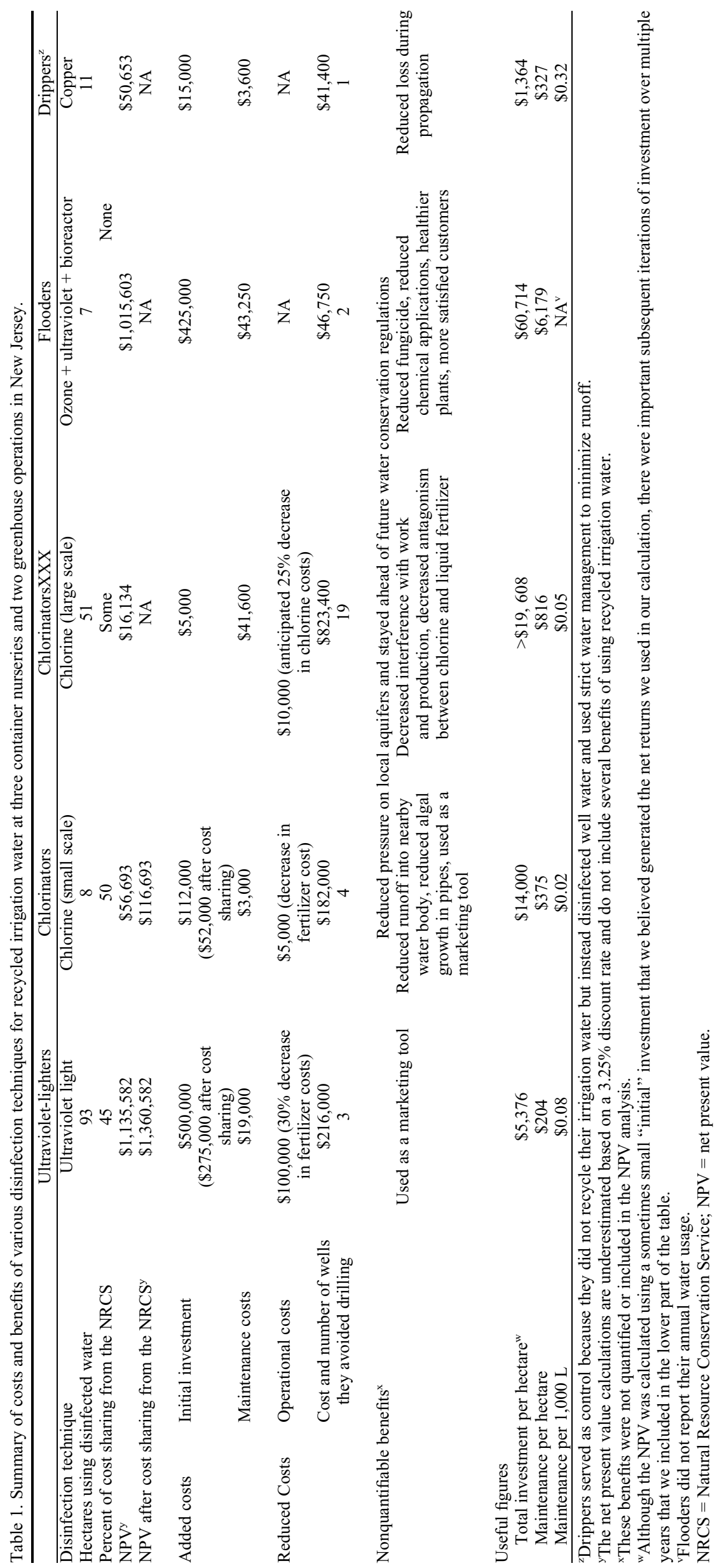


All NPV values were likely underestimated because it was more difficult for growers to attribute certain benefits to their recycling and disinfection systems than it was to attribute costs. All three nurseries had positive NPV values, which reveal profitable investments, although this was not the main motivation for any of the growers. It is clear that financial assistance from the NRCS helped generate a significant return on the investments of the Ultraviolet-lighters and Chlorinators, who recycled half of their irrigation runoff.

Profitability was greatest for the Ultraviolet-lighters, who used ultraviolet light to treat the largest number of hectares and reported the largest quantifiable benefit - a 30\% reduction in fertilizer costs, which was estimated based on their current expenses. This was a surprise to the Ultraviolet-lighters, who made this investment to protect the future of their operation in anticipation of water containment laws and did not expect to see any return on their investment.

The Chlorinator's recycling system may not have been possible without the assistance from the NRCS. The cost sharing nearly doubled the NPV of their current system, which required only $\$ 3000$ annual maintenance but saved an estimated $\$ 5000$ annually from reduced fertilizer use. The NRCS funded their project because the Chlorinators had a containment issue with runoff entering a river that runs through their property. At one time, there were more than 550 LPM water running into this river, and the grower did not want to lose this water while continuing to pump out of the ground. This project built two containment ponds where water was treated with chlorine gas and reused on most of the property, but several plants did not responded well to the chemically treated water and were irrigated with well water.

Chlorinators XXX appear to have the least profitable recycling investment of the nurseries, which can be partially explained by their annual maintenance costs that are more than double that of the other operations. They only reported a slight reduction in chlorine costs due to new construction, and we could not quantify many other benefits in marketing, quality, and yield. The ChlorinatorXXX installed one of the first chlorination disinfection systems in New Jersey, which has let them collect and reuse irrigation runoff for over 20 years. They initially used a vacuum system to treat their runoff with chlorine gas (a method that the Chlorinators use) but recently invested in a large construction project that overhauled their disinfection technique. They now pump from a primary tailwater recovery basin, treat with varying rates of chlorine gas based on oxidationreduction potential, and then move it to a new recycled basin before it is used.

This new recycling system increased their pump capacity to $\approx 30,000$ LPM to address their increased water demand due to expansion, and was automated for safety and convenience. The Chlorinators XXX already recycled two-thirds of their irrigation runoff, but anticipated higher efficiency with this system. This nursery also received assistance from the NRCS, but could not provide financial data because of the large size of their projects. They valued the technical assistance from the NRCS, who developed a strong relationship with this grower over the years.

Both greenhouses appeared to have lost money on their water recycling investments, but these numbers do not tell the entire story. Table 1 seems to show a significant NPV difference between greenhouses and nurseries, but with such a small sample, this could easily have happened by chance. The Flooders were extremely satisfied with their system and reported a large number of benefits that were not translated into dollar amounts, such as improved plant health, decreased fungicide use, a cleaner operation, and the ability to produce virtually no runoff. Our control greenhouse made the smallest investment and was probably profitable because it would not take a large amount of annual benefits, such as reduction in loss during propagation (which we did not quantify) to offset their small annual maintenance costs.

Fresh water availability is on track to dwindle in the coming years, and this could threaten the livelihood of the horticultural industry if growers do not manage their water in an environmentally responsible manner. Although there are many water disinfection and recycling systems on the market, perception issues may still exist for years to come. Growers in Florida initially rejected the idea of using recycled irrigation water in the 1980 s because of concerns over plant damage from salinity and disease organisms, but most of those growers accept recycled water now (Parsons et al., 2010).

Unfortunately, according to a nationwide survey of greenhouse and nursery crop growers, only half of the growers used any type of water conservation measures and only $12 \%$ were interested in implementing water conservation measures in the near future. They felt the biggest obstacle toward such sustainable practices was incompatibility with their existing system of production (Dennis et al., 2010). Government regulations have been implemented in California that require growers to contain all water on their property or treat all water leaving their property and have begun to spread to the rest of the country. These regulations are starting to deal with nonpoint water runoff, which is what most ornamental operations are considered.

Our results show these three nurseries were able to safely invest in water recycling systems without jeopardizing their business profitability, although they may not see an immediate or obvious return on investment. These successes reveal the importance of public investment by the NRCS, and our policy recommendation is a larger budget for this program to increase their influence to as many operations as possible. Growers who are looking to make this type of investment can benefit from financial assistance, but they should not underestimate the technical guidance that NRCS offers. Each grower we interviewed strongly suggested receiving input, advice, and guidance from industry experts to make an informed decision. The NRCS provides all of this (and more) and every grower should know about this valuable resource.

The benefits of recycling irrigation water should satisfy a grower's personal preferences to make it a worthwhile investment. The two greenhouses in this study produced the same amount of (negligible) runoff, however they illustrated opposite approaches to water management: flood floors and drip irrigation. Greenhouses with high-quality standards and available capital can benefit from a three-pronged disinfection system with flood floors. Unfortunately, such a system requires new construction or completely retrofitting an old greenhouse. A cheaper and effective alternative to reduce water use dramatically is to adopt a wet/dry watering cycle as the Drippers have done, however it may require considerable oversight.

Water management and water recycling are sure to be topics of discussion for years to come as fresh water resources are compromised. Size, plant variety and quality, and capital are just a few of the variables that can affect the success or failure of a recycling and disinfection system. Growers planning to overhaul their irrigation techniques and begin recycling should consider all of their options, plan for expansion down the road, and accept the reality that they may not see a financial return from this investment. However, benefits to the operations and environment from recycling irrigation water suggest an imminent adaptation in water-scarce areas.

\section{Literature Cited}

Alcon, F., J. Martin-Ortega, F. Pedrero, J.J. Alarcon, and M. Dolores de Miguel. 2012. Incorporating non-market benefits of reclaimed water into cost-benefit analysis: A case study of irrigated mandarin crops in southern Spain. Water Resources Mgt. 27:1809-1820.

Amarasinghe, U.A. and V. Smakhtin. 2014. Global water demand projections: Past, present, and future. International Water Management Institute (IWMI), Colombo, Sri Lanka. (IWMI Research Report 156).

Anonymous. 2009. The Water Conservation Act of 2009. Senate Bill SB X7-7. California Department of Water Resources. 5 Mar. 2014. <http:// www.water.ca.gov/wateruseefficiency/sb7/docs/ SB7-7-TheLaw.pdf>.

Bankrate. 2015. Wall Street journal prime rate. 30 May 2015. <http://www.bankrate.com/rates interest-rates/wall-street-prime-rate.aspx $>$.

Cayanan, D.F., Y. Zheng, P. Zhang, T. Graham, M. Dixon, C. Chong, and J. Llewellyn. 2008 Sensitivity of five container-grown nursery species to chlorine in overhead irrigation water. HortScience 43:1882-1887.

Chen, W., S. Lu, W. Jiao, M. Wang, and A.C. Chang. 2013. Reclaimed water: A safe irrigation water source? Environ. Dev. 8:74-83.

Circle of Blue. 2015. Price of water 2015: Up 6 percent in 30 major U.S. cities; 41 percent rise 
since 2010. 29 Apr. 2015. <http://www. circleofblue.org/waternews/2015/world/priceof-water-2015-up-6-percent-in-30-major-u-s-cities41-percent-rise-since-2010/>.

Dennis, J.H., R.G. Lopez, B.K. Behe, C.R. Hall, C. Yue, and B.L. Campbell. 2010. Sustainable production practices adopted by greenhouse and nursery plant growers. HortScience 45:1232-1237.

Economics Consulting Service. 2008. The feasibility of a new horticulture precinct on the Gnangara Mound: Report prepared for the Department of Agriculture and Food. 20 Aug. 2014. $<$ http://www.water.wa.gov.au/PublicationStore/ first/85173.pdf>.

Fisher, P., J. Huang, R. Freyre, and R. Dickson. 2015. Too wet or too dry? Grower Talks. 5 May 2015. <http://www.ballpublishing.com/growertalks/ ViewArticle.aspx?articleid=21384>.

Global Water Partnership. 2000. Integrated water resource management. Technical Advisory Committee Background Papers No. 4. 1 Jan. 2015. < http:// www.gwp.org/Global/ToolBox/Publications/ Background $\% 20$ papers/04\%20Integrated $\%$ 20Water\%20Resources $\% 20$ Management $\%$ 20(2000)\%20English.pdf>.

Hall, C.R., B.J. Campbell, B.K. Behe, C. Yue, R.G. Lopez, and J.H. Dennis. 2010. The appeal of biodegradable packaging to floral consumers. HortScience 45:583-591.

Hong, C., J.D. Lea-Cox, D.S. Ross, G.W. Moorman, P.A. Richardson, S.R. Ghimire, and P. Kong. 2008. Containment basin water quality fluctuation and implications for crop health management. Irr. Sci. 27:485-496.
Keat, P.G. and P.K. Young. 1996. Managerial economics: Economic tools for today's decision makers. 2nd ed. Prentice Hall, Upper Saddle River, NJ.

Majsztrik, J.C., A.G. Ristvey, and J.D. Lea-Cox. 2011. Water and nutrient management in the production of container-grown ornamentals. Hort. Rev. 38:253-297.

Meador, D.P., P.R. Fisher, P.F. Harmon, N.A Peres, M. Teplitski, and C.L. Guy. 2012. Survey of physical, chemical, and microbial water quality in greenhouse and nursery irrigation water. HortTechnology 22:778-786.

Norton-Brandao, D., S.M. Scherrenberg, and J.B. van Lier. 2013. Reclamation of used waters for irrigation purposes: A review of treatment technologies. J. Environ. Mgt. 122:85-98.

Parsons, L.R., B. Sheikh, R. Holden, and D.W. York. 2010. Reclaimed water as an alternative water source for crop irrigation. HortScience 45:1626-1629.

Pimentel, D., J. Houser, E. Preiss, O. White, H. Fanag, L. Mesnick, T. Barsky, S. Tariche, J. Schreck, and S. Alpert. 1997. Water resources: agriculture, the environment, and society. BioScience 47:97-106.

Powell, C.C. 2014. Are your plants drinking dirty water? Grower Talks. 5 Mar. 2014 $<$ http://www.ballpublishing.com/GrowerTalks/ ViewArticle.aspx?articleID=14794\&>.

Schulte, P. 2011. Using reycled water on agriculture: Sea Mist Farms and Sonoma County. Pacific Institute. 10 Feb. 2014. <http://agwaterstewards. org/images/uploads/docs/recycled_water_and_ agriculture3.pdf $>$.

Stewart-Wade, S.M. 2011. Plant pathogens in recycled irrigation water in commercial plant nurseries and greenhouses: Their detection and management. Irr. Sci. 29:267-297.

UMass Amherst Extension. 2013. Bacterial diseases of geranium. Greenhouse Crops and Floriculture Program. 10 Jan. 2014. <http:// extension.umass.edu/floriculture/fact-sheets/ bacterial-diseases-geranium $>$.

USDA Natural Resource Conservation Service New Jersey. 2014. Financial Assistance. 5 Mar. 2014. <http://www.nrcs.usda.gov/wps/ portal/nrcs/main/nj/programs/financial/>.

U.S. Department of Health \& Human Services. 2009. Code of Federal Regulations for Human Subjects Research (45 CFR 46). 5 Mar. 2014 <http://www.hhs.gov/ohrp/humansubjects/ guidance/45cfr46.html\#46.101>.

Uva, W.L. and T.C. Weiler. 2001. Economic analysis of adopting zero runoff subirrigation systems in greenhouse operations in the northeast and north central United States. HortScience 36:167-173.

World Bank. 2006. Reengaging in agricultural water management: Challenges and options. 25 Aug. 2014. <http://siteresources.worldbank. org/INTARD/Resources/DID_AWM.pdf>.

Yeager, T.H. 2008. Capture and recycling of irrigation water. In: Green industry knowledge center for water and nutrient management learning modules. Univ. Maryland, College Park, MD. 1 Aug. 2014. <http://www.waternut. org/moodle/course/view.php?id=21>.

Zheng, Y., L. Wang, and M.A. Dixon. 2004 Response to copper toxicity for three ornamental crops in solution culture. HortScience 39:1116-1120. 